\title{
PENGARUH GAJI DAN TUNJANGAN TERHADAP KINERJA KARYAWAN HOTEL NATAMA SYARIAH PADANGSIDIMPUAN
}

\author{
Nofinawati \\ Institut Agama Islam Negeri Padangsidimpuan \\ Email : nofinawati82@gmail.com
}

\begin{abstract}
Abstrak,
Gaji dan tunjangan sangat berpengaruh dalam menentukan pencapain kinerja karyawan pada Hotel Natama Syariah Padangsidimpuan. Kinerja karyawan pada hotel ini masih belum terlaksana dengan baik, karena beberapa karyawan tidak melaksanakan tugasnya masingmasing dengan maksimal sedangkan gaji diberikan tepat pada waktunya. Penelitian ini merupakan penelitian kuantitatif, populasi yang digunakan dalam penelitian ini seluruh karyawan pada Hotel Natama Syariah Padangsidimpuan, dengan pengambilan sampel yaitu sampling jenuh sebanyak 27 responden. Hasil penelitian yang dilakukan diperoleh hasil uji koefisien determinasi $\left(\mathrm{R}^{2}\right)$ sebesar 0,709, hal ini menunjukkan bahwa persentase pengaruh variabel gaji dan tunjangan terhadap kinerja karyawan sebesar 70,9\%. Sedangkan sisanya sebesar 29,1\% dipengaruhi oleh variabel lain yang tidak dimasukkan dalam model penelitian ini. Secara simultan menyatakan bahwa terdapat pengaruh antara gaji dan tunjangan secara bersama-sama terhadap kinerja karyawan pada Hotel Natama Syariah Padangsidimpuan, dengan nilai $F_{\text {hitung }}$ 29,212 dan $F_{\text {tabel }} 2,54$. Maka terdapat pengaruh yang positif antara gaji dan tunjangan terhadap kinerja karyawan pada Hotel Natama Syariah Padangsidimpuan. Secara parsial gaji tidak mempunyai pengaruh terhadap kinerja karyawan Hotel Natama Syariah Padangsidimpuan dengan nilai $t_{\text {hitung }}<t_{\text {tabel }}$ yaitu $1,354<1,710$. Secara parsial tunjangan mempunyai pengaruh terhadap kinerja karyawan Hotel Natama Syariah Padangsidimpuan dengan nilai $t_{\text {hitung }}>t_{\text {tabel }}$ yaitu: $1,836>1,710$.
\end{abstract}

Kata Kunci : Gaji, Tunjangan, Kinerja

\begin{abstract}
,
Salaries and benefits are very influential in determining the achievement of employee performance at the Natama Syariah Hotel Padangsidimpuan. The employee's performance at this hotel is still not well implemented, because some employees do not carry out their respective duties to the maximum while the salary is given on time. This study is a quantitative study, the population used in this study were all employees at the Natama Syariah Hotel Padangsidimpuan, with sampling of 27 respondents saturated sampling. The results of the research carried out obtained the test results of the coefficient of determination (R2) of 0.709 , this indicates that the percentage effect of variable salaries and benefits on employee performance is $70.9 \%$. While the remaining $29.1 \%$ is influenced by other variables not included in this research model. Simultaneously states that there is an influence between salary and benefits together on employee performance at the Natama Syariah Hotel Padangsidimpuan, with F value of 29.212 and Ftable 2.54. Then there is a positive influence between salary and benefits on employee performance at the Natama Syariah Hotel Padangsidimpuan. Partially salaries do not have an effect on the performance of employees of the Natama Syariah Hotel Padangsidimpuan with a tcount <ttable which is $1.354<1.710$. Partially the benefits have an influence on the performance of employees of the Natama Syariah Hotel Padangsidimpuan with a tcount $>$ ttable which is 1.836>1.710.
\end{abstract}

Keyword : Salary, Benefits, Performance 


\section{PENDAHULUAN}

Pada era globalisasi ini, perusahaan-perusahaan lokal baik swasta maupun Badan Usaha Milik Negara (BUMN) dituntut untuk bersaing lebih ketat dengan perusahaanperusahaan asing. Aset paling penting yang harus dimiliki oleh organisasi atau perusahaan adalah tenaga kerja atau Sumber Daya Manusia (SDM). Sumber Daya Manusia (SDM) pernah didefinisikan sebagai orang-orang yang merancang dan menghasilkan barang atau jasa, mengawasi mutu, memasarkan produk, mengalokasikan sumber daya finansial, mengadakan inovasi, serta merumuskan seluruh strategi dan tujuan organisasi.

Organisasi harus memiliki dan mempertahankan karyawan terbaik, tercerdas dan memiliki ragam inovasi. Organisasi juga harus memiliki karyawan yang dapat bekerjasama untuk menghasilkan produk lebih baik dan lebih cepat di tempat kerja. Keunggulan bersaing organisasi ditentukan kualitas Sumber Daya Manusianya. Oleh karena itu, penanganan Sumber Daya Manusia harus dilakukan secara menyeluruh dan seksama dalam kerangka sistem pengelolaan Sumber Daya Manusia yang strategis, menyatu, selalu terhubung, sesuai tujuan dan visi misi organisasi.

Kinerja adalah hasil kerja yang dapat dicapai oleh seseorang atau kelompok orang dalam suatu organisasi, sesuai dengan wewenang dan tanggung jawab masing-masing dalam rangka upaya mencapai tujuan organisasi bersangkutan secara legal tidak melanggar hukum sesuai dengan moral maupun etika. Tinggi rendahnya kinerja pekerja berkaitan erat dengan sistem pemberian penghargaan yang ditetapkan oleh lembaga atau organisasi tempat mereka bekerja (Rahadi, 2010).

Karyawan dengan kinerja yang baik diberikan penghargaan berupa gaji. Gaji merupakan nilai dalam bentuk uang yang ditetapkan menurut suatu persetujuan, undangundang, dan peraturan, serta dibayarkan atas dasar suatu perjanjian kerja antara pemberi kerja dan penerima kerja. Gaji adalah balas jasa dalam bentuk uang yang diterima pegawai sebagai konsekuensi dari kedudukannya sebagai seorang pegawai atau karyawan yang memberikan sumbangan tenaga dan pikiran dalam sebuah perusahaan (Sucipto, 2010).

Gaji merupakan salah satu alasan bagi karyawan untuk bekerja dan salah satu alasan yang paling penting bagaimana seorang karyawan dapat berprestasi, berafiliasi dengan orang lain, mengembangkan diri dan aktualisasi diri. Memberikan gaji menjadi salah satu faktor penting dalam meningkatkan kepuasan kerja, memotivasi pegawai, merangsang pegawai baru yang berkualitas untuk memasuki organisasi dan mempertahankan pegawai yang ada.

Tunjangan atau fringe benefits merupakan salah satu bentuk pemberian kompensasi berupa penyediaan paket benefits dan program-program pelayanan karyawan, dengan maksud pokok untuk mempertahankan keberadaan karyawan sebagai anggota organisasi dalam jangka panjang. Fringe benefits merupakan kompensasi tidak langsung, karena tidak 
langsung berkaitan dengan prestasi kerja. Meskipun demikian pemberian kompensasi pelengkap ini menjadi semakin penting bagi organisasi (Samsudin, 2010).

Hotel Natama Syariah Padangsidimpuan yang beralamat di Jl. Sisingamangaraja No. 100 Padangsidimpuan, kelurahan Sitamiang Kec. Padangsidimpuan Batunadua, kota Padangsidimpuan, Sumatera Utara, merupakan hotel yang berbasis syariah yang ada di Padangsidimpuan. Pada Hotel Natama Syariah Padangsidimpuan memiliki peraturan yang sesuai dengan prinsip syariah seperti berpakaian, karyawan harus disesuaikan dengan syariah serta pada saat waktu sholat tiba, karyawan melakukan sholat secara bergantian dengan pergantian shif agar karyawan dapat melaksanakan sholat.

Kinerja karyawan dari segi tanggung jawab masih ada saja karyawan yang lalai dalam bekerja, yaitu kinerja karyawan security atau penjaga keamanan yang tidak bertanggung jawab dalam melakukan tugasnya, dimana security tersebut sering tidur pada saat jam bekerja sehingga keamanan hotel tersebut tidak ada. Serta apabila mengalami kesibukan dimana pengunjung atau tamu lebih banyak, yang menyebabkan pelayanan berkurang dan kinerja menurun, padahal dengan banyaknya pengunjung atau tamu dapat menambah gaji atau bonus karyawan (Samsudin, 2010).

Pemberian gaji kepada karyawan sesuai dengan upah minimum regional yang diberikan kepada karyawan tetap saja. Dimana karyawan bisa dikatakan karyawan tetap terletak lamanya waktu kerja. karyawan tetap memiliki masa kerja lebih lama bisa lima hingga sepuluh tahun setelah diangkat menjadi karyawan tetap. Sedangkan karyawan tidak tetap mereka bekerja tiga atau enam bulan bahkan satu tahun batasannya tiga tahun saja. Karyawan tetap adalah karyawan yang menerima penghasilan dalam jumlah tertentu secara teratur dan terus menerus. Karyawan tidak tetap adalah karyawan yang menerima penghasilan hanya apabila karyawan bekerja berdasarkan jumlah hari kerja.

Tunjangan yang diberikan pada karyawan Hotel Natama Syariah seperti: BPJS ketenagakerjaan, BPJS kesehatan, tunjangan jabatan dan tunjangan disiplin. Karyawan yang hadir dan pulang tepat pada waktunya, sebagai bukti dengan mengisi absen. Pengunjung atau tamu pada Hotel Natama Syariah relatif, tergantung adanya acara atau momen seperti acara pemilu, hari-hari besar, dan lain-lain. Berdasarkan fenomena di atas, maka peneliti tertarik untuk melakukan penelitian yang berjudul "Pengaruh Gaji Dan Tunjangan Terhadap Kinerja Karyawan Hotel Natama Syariah Padangsidimpuan”.

\section{TINJAUAN TEORITIK}

Gaji

Dessler dalam buku Sadili Samsudin mengatakan gaji adalah sesuatu yang berkaitan dengan uang yang diberikan kepada pegawai atau karyawan. Ia berpendapat bahwa sistem 
pembayaran dapat dibedakan berdasarkan waktu kinerjanya, yaitu pembayaran yang dilakukan atas dasar lamanya bekerja, misalnya per jam, hari, minggu, bulan, dan sebagainya. Pembayaran berdasarkan hasil kerja, yaitu pembayaran upah/gaji yang didasarkan pada hasil akhir dari proses kinerja, misalnya jumlah produksi. Amstrong dan Murlis, dalam bukunya Pedoman Praktis Sistem Penggajian, berpendapat gaji merupakan bayaran pokok yang diterima oleh seseorang (Samsudin, 2010).

Gaji adalah pemberian uang secara langsung yang diberikan kepada seorang karyawan secara periodik (biasanya sebulan sekali). Karyawan yang menerima gaji pada umumnya telah menjadi karyawan tetap yang telah lulus dari masa percobaan (Handoko, 2009). Gaji adalah uang yang dibayarkan kepada karyawan berdasarkan periode waktu. Dalam menentukan besarnya upah dan gaji yang diberikan perusahaan mempertimbangkan besarnya upah dan gaji yang diberikan kompetitor kepada para karyawannya (Sunardi dan Primasitiwi, 2012).

\section{Tunjangan}

Menurut Dessler tunjangan (benefits) adalah menggambarkan satu bagian penting dari setiap upah karyawan sebagai semua pembayaran keuangan tidak langsung yang diterima seorang karyawan untuk melanjutkan pekerjaannya dengan perusahaan. Tunjangantunjangan umumnya tersedia bagi semua karyawan sebuah perusahaan dan meliputi hal-hal seperti waktu cuti yang dibayar, asuransi jiwa dan kesehatan, dan fasilitas pengasuhan anak (Dessler, 1998).

Menurut Handoko (2001) tunjangan merupakan bentuk kompensasi pelengkap, sering disebut fringe benefits adalah untuk mempertahankan karyawan dalam jangka panjang. Kompensasi pelengkap ini berbentuk penyediaan paket benefits dan penyelenggaraan program-program pelayanan karyawan, benefits dan pelayanan tersebut merupakan kompensasi tidak langsung (indirect compensation).

Tunjangan merupakan bentuk kompensasi tidak langsung (indirect compensation) yaitu pemberian kompensasi kepada karyawan sebagai tambahan yang didasarkan kepada kebijakan pimpinan dalam rangka upaya meningkatkan kesejahteraan karyawan. Tentunya pemberian kompensasi ini tidak secara langsung berkaitan dengan pekerjaan yang dilakukan oleh karyawan tersebut (Sofyandi, 2008).

Kinerja Karyawan

Dalam bahasa Inggris istilah kinerja adalah performance, performance merupakan kata benda. Salah satu entry-nya adalah thing done (sesuatu hasil yang telah dikerjakan). Menurut Fattah dalam buku Dedi Rianto Rahadi kinerja atau prestasi kerja (performance) diartikan sebagai ungkapan kemampuan yang didasari oleh pengetahuan, sikap dan keterampilan dan motivasi dalam menghasilkan sesuatu. Sedarmayanti dalam buku Dedi Rianto Rahadi kinerja merupakan terjemahan dari performance yang berarti prestasi kerja, pelaksana kerja, pencapaian kerja, unjuk kerja atau penampilan kerja (Rahadi, 2010). 
Dessler mengatakan kinerja hampir sama dengan prestasi kerja ialah perbandingan antara hasil kerja aktual dengan standar kerja yang ditetapkan, dalam hal ini kinerja lebih memfokuskan pada hasil kerja (Dessler, 2007).

\section{METODE PENELITIAN}

Penelitian ini dilakukan di Hotel Natama Syariah Padangsidimpuan dengan menggunakan metode penelitian kuantitatif. Penelitian dengan pendekatan kuantitatif menekankan analisisnya pada data-data angka yang diolah dengan metode statistik untuk menjawab pertanyaan atau hipotesis penelitian yang sifatnya spesifik, dan untuk melakukan prediksi bahwa suatu variabel tertentu memengaruhi variabel yang lain (Azwar, 2004).

Instrumen pengumpulan data dalam penelitian ini menggunakan kuesioner yaitu pengumpulan data dengan memberikan daftar pertanyaan kepada pegawai Hotel Natama Syariah Padangsidimpuan dengan cara: (1). Membagikan kuesioner,(2). Responden diminta mengisi kuesioner pada lembar jawaban yang telah disediakan, (3). Kemudian lembar kuesioner dikumpulkan, diseleksi, diolah dan kemudian dianalisis. Skala yang digunakan adalah skala likert. Skala likert adalah skala yang berisi lima tingkat jawaban yang merupaka skala ordinal. Dimana skala likert ini merupakan cara yang paling sering digunakan dalam menentukan skor.

Penelitian in mengambil datanya dengan membagikan kuesioner, maka penelitian in menggunakan uji validitas dan reliabilitas. Validitas merupakan suatu ukuran yang menunjukkan tingkat-tingkat kesahian suatu instrument. Suatu instrument pengukuran dikatakan valid jika instrumen dapat mengukur sesuatu dengan tepat apa yang hendak diukur. Perhitungan menggunakan rumus koefesien korelasi product moment dari Karl Pearson, yaitu dengan menggunakan SPSS Versi 21,0.

Dan uji reliabilitas adalah Suatu instrument pengumpulan data dikatakan reliabilitas jika pengukurannya konsisten (cermat) dan akurat.Jadi, uji reliabilitas instrument dilakukan dengan tujuan mengetahui konsistensi dari instrument sebagai alat ukur sehingga hasil pengukuran dapat dipercaya. Dengan menggunakan formula cronbach alfa,dimana secara umum yang danggap reliabel apabila nilai cronbach alfa> 0,6.

\section{Uji Normalitas}

Uji normalitas adalah uji yang bertujuan untuk melihat apakah kelompok data berdistribusi normal atau tidak.Uji normalitas dilakukan dengan mendasarkan pada uji Kolmogorov Smirnow (KS).Kriteria yang digunakan adalah apabila hasil perhitungan KS lebih besar dari 0,05 maka data berdistribusi normal (Sugiono dan susanto, 2015).

\section{Uji Multikolinearitas}


Uji multikolinearitas adalah adanya lebih dari satu hubungan linear yang sempurna antara variabel-variabel bebas dalam model regresi.Syaratnya dengan melihat nilai tolerance dan variance factor (VIF) pada model regresi. Jika nilai toleransi dari o,1 maka tidak terjadi multikolinearitas dan jika nilai (VIF) kurang dari 10, maka tidak terjadi multikolinearitas.

\section{Uji Heteroskedastisitas}

Heteroskedastisitas adalah varian residual yang tidak konstan pada regresi sehingga akurasi hasil prediksi menjadi meragukan.Heteroskedastitas dapat diartikan sebagai ketidaksamaan variasi variabel pada semua pengamatan, dan kesalahan yang terjadi memperlihatkan hubungan yang sistematis sesuai dengan besarnya satu atau lebih variabel bebas sehingga kesalahan tersebut tidak random (acak).Teknik yang digunakan adalah uji koefesien korelasi spearman's rho ialah mengorelasikan variabel independen dengan residual. Pengujian menggunakan tingkat signifikan o,o5 dengan uji 2 sisi. Jika korelasi antara variabel independen dengan residual didapat signifikansi lebih dari o,05 maka dapat dikatakan bahwa tidak terjadi heteroskedastitas. Apabila yang kita hadapi mempunyai skala ordinal, maka korelasi product moment tidak dapt digunakan.

\section{Uji Autokrelasi}

Uji autokorelasi adalah korelasi antara sesama urutan pengamatan dari waktu ke waktu (Umar, 2013). Auto korelasi terjadi jika angka Durbin Watson (DW) dibawah -2 atau diatas +2 , dan tidak terjadi autokorelasi jika angka Durbin Watson (DW) dantara -2 dan +2 (Sarwono, 2015). Dalam penelitian ini, peneliti tidak menggunakan autokorelasi karena peneliti tidak menggunakan time series.

\section{Persamaan Regresi Linear Berganda}

Analisis regresi berganda digunakan untuk mengetahui bagaimana pengaruh variabel independen disiplin kerja $\left(\mathrm{X}_{1}\right)$, etika $\left(\mathrm{X}_{2}\right)$, terhadap variabel dependen yaitu kinerja pegawai. Adapun bentuk persamaan regresi linear berganda yang digunakan dalam penelitian ini sebagai berikut :

$$
\mathrm{Y}=\mathrm{a}+\mathrm{b}_{1} \mathrm{X}_{1}+\mathrm{b}_{2} \mathrm{X}_{2}+\mathrm{b}_{3} \mathrm{X}_{3}
$$

Sehingga dalam penelitian ini persamaan regresi linear berganda adalah:

$$
\mathrm{DK}=\mathrm{a}+\mathrm{b}_{1} \mathrm{HK}+\mathrm{b}_{2} \mathrm{TP}+\mathrm{b}_{3} \mathrm{BJ} / \mathrm{G}
$$

\section{Koefesien Determinasi}

Analisa determinasi dalam regresi linear berganda digunakan untuk mengetahui persentase sumbangan pengaruh variabel idependen secara serentak terhadap variabel independen.Koefesien ini menunjukkan seberapa besar persentaese variasi variabel dependen.Semakin besar nilai $\mathrm{R}^{2}$ (mendekati 1 ), maka ketepatannya dikatakan semakin baik.Maka dapatdikatakan bahwa variabel independen adalah besar terhadap variabel dependen (Setiawan dan Kusrini, 2010). 


\section{Uji t dan Uji f}

Uji t digunakan untuk mengetahui pengaruh masing-masing variable independen terhadap variable dependen, maka digunakan tingkat signifikasi o,05. Setelah $t_{\text {hitung }}$ diproleh, maka untuk mnginterprestasikan hasilnya berlaku ketentuan sebagai berikut:

$$
\begin{aligned}
& \text { Jika }-\mathrm{t} \text { tabel }<\mathrm{t} \text { hitung }<\mathrm{t} \text { tabel maka } \mathrm{H}_{\mathrm{o}} \text { diterima. } \\
& \text { Jika }-\mathrm{t} \text { hitung }<- \text { tabel atau } \mathrm{t} \text { hitung }>\mathrm{t} \text { tabel maka } \mathrm{H}_{\mathrm{o}} \text { ditolak. }
\end{aligned}
$$

Uji F dilakukan untuk mengetahui pengaruh variabel independen terhadap variabel dependen secara simultan atau untuk mengetahui apakah model regresi dapat digunakan untuk memprediksi variabel dependen atau tidak. Adapun kriteria pengujian ini sebagai berikut: Apabila nilai $\mathrm{F}$ hitung $<\mathrm{F}$ table atau nilai signifikansi $\mathrm{F}<0$, 05 maka $\mathrm{H}_{\mathrm{o}}$ diterima artinya tidak ada pengaruh secara bersama-sama atau serentak antara variabel independen terhadap variabel dependen.

Apabila nilai $\mathrm{F}$ hitung $>\mathrm{F}$ tabel atau nilai signifikansi $\mathrm{F}>0,05$ maka $\mathrm{H}_{\mathrm{o}}$ ditolak artinya ada pengaruh secara bersama-sama atau serentak antara variabel independen terhadap variabel dependen.

\section{HASIL DAN PEMBAHASAN}

\section{Uji Validitas}

Uji validitas digunakan untuk mengetahui tingkat kesahihan instrumen dalam pengumpulan data. Uji validitas dilakukan dengan membandingkan nilai $\mathbf{r}_{\text {hitung }}$ dengan nilai $\mathrm{r}_{\text {tabel. }}$ Hasil dari uji validitas penelitian sebagai berikut.

\begin{tabular}{|c|c|c|c|}
\hline $\begin{array}{c}\text { Item } \\
\text { Pernyataan }\end{array}$ & r hitung & $\mathrm{r}$ tabel & Keterangan \\
\hline 1 & 0,842 & \multirow{13}{*}{$\begin{array}{c}\text { Instrumen valid jika } \mathrm{r}_{\text {hitung }}> \\
\mathrm{r}_{\text {tabel }} \text { dengan } \mathrm{n}=25 . \text { Pada } \\
\text { taraf signifikan } 10 \% \\
\text { sehingga diperoleh } \mathrm{r}_{\text {tabel }}= \\
0,323\end{array}$} & Valid \\
\hline 2 & 0,821 & & Valid \\
\hline 3 & 0,728 & & Valid \\
\hline 4 & 0,810 & & Valid \\
\hline 5 & 0,887 & & Valid \\
\hline 6 & $-0,059$ & & Tidak Valid \\
\hline 7 & $-0,226$ & & Tidak Valid \\
\hline 8 & 0,664 & & Valid \\
\hline 9 & 0,608 & & Valid \\
\hline 10 & 0,755 & & Valid \\
\hline 11 & 0,862 & & Valid \\
\hline 12 & $-0,191$ & & Tidak Valid \\
\hline 13 & 0,401 & & Valid \\
\hline
\end{tabular}

Tabel 1. Hasil Uji Validitas Variabel Gaji (X1)

Sumber: Data diolah dari hasil SPSS Versi 22. 
Hasil uji validitas dari tabel di atas dapat diketahui bahwa dari seluruh item pernyataan tiga diantaranya tidak valid yaitu: -0,059 < 0,323, -0,226 < 0,323 dan -0,191< 0,323 .

Tabel 2. Hasil Uji Validitas Variabel Tunjangan (X2)

\begin{tabular}{|c|c|c|c|}
\hline $\begin{array}{c}\text { Item } \\
\text { Pernyataan }\end{array}$ & r hitung & $\mathrm{r}$ tabel & Keterangan \\
\hline 1 & 0,813 & \multirow{11}{*}{$\begin{array}{c}\text { Instrumen valid jika } \mathrm{r}_{\text {hitung }}> \\
\mathrm{r}_{\text {tabel }} \text { dengan } \mathrm{n}=25 . \text { Pada } \\
\text { taraf signifikan } 10 \% \\
\text { sehingga diperoleh } \mathrm{r}_{\text {tabel }}= \\
0,323\end{array}$} & Valid \\
\hline 2 & 0,854 & & Valid \\
\hline 3 & 0,914 & & Valid \\
\hline 4 & $-0,241$ & & Tidak Valid \\
\hline 5 & 0,828 & & Valid \\
\hline 6 & 0,722 & & Valid \\
\hline 7 & 0,700 & & Valid \\
\hline 8 & 0,777 & & Valid \\
\hline 9 & 0,776 & & Valid \\
\hline 10 & 0,718 & & Valid \\
\hline 11 & 0,642 & & Valid \\
\hline
\end{tabular}

Sumber: Data diolah dari hasil SPSS Versi 22.

Hasil uji validitas dari tabel di atas bahwa dari seluruh item pernyataan satu diantaranya $\mathrm{r}_{\text {hitung }}<\mathrm{r}_{\text {tabel, }}$ maka dapat disimpulkan bahwa $-0,241<0,323$ dinyatakan tidak valid.

Tabel 3. Hasil Uji Validitas Variabel Kinerja Karyawan (Y)

\begin{tabular}{|c|c|c|c|}
\hline $\begin{array}{c}\text { Item } \\
\text { Pernyataan }\end{array}$ & r hitung & $\mathrm{r}$ tabel & Keterangan \\
\hline 1 & 0,702 & \multirow{19}{*}{$\begin{array}{c}\text { Instrumen valid jika } \mathrm{r}_{\text {hitung }}> \\
\mathrm{r}_{\text {tabel }} \text { dengan } \mathrm{n}=25 . \text { Pada } \\
\text { taraf signifikan } 10 \% \\
\text { sehingga diperoleh } \mathrm{r}_{\text {tabel }}= \\
0,323\end{array}$} & Valid \\
\hline 2 & 0,527 & & Valid \\
\hline 3 & 0,708 & & Valid \\
\hline 4 & 0,744 & & Valid \\
\hline 5 & 0,706 & & Valid \\
\hline 6 & 0,621 & & Valid \\
\hline 7 & 0,805 & & Valid \\
\hline 8 & 0,761 & & Valid \\
\hline 9 & 0,504 & & Valid \\
\hline 10 & 0,355 & & Tidak Valid \\
\hline 11 & 0,480 & & Valid \\
\hline 12 & $-0,282$ & & Tidak Valid \\
\hline 13 & 0,721 & & Valid \\
\hline 14 & 0,608 & & Valid \\
\hline 15 & 0,777 & & valid \\
\hline 16 & 0,556 & & Valid \\
\hline 17 & 0,493 & & Valid \\
\hline 18 & $-0,207$ & & Tidak Valid \\
\hline 19 & 0,562 & & Valid \\
\hline
\end{tabular}

Sumber: Data diolah dari hasil SPSS Versi 22

Hasil uji validitas di atas dapat diketahui dari seluruh item pernyataan tiga diantaranya tidak valid yaitu: $0.355<0,323,-0,282<0,323$ dan $-0,207<0,323$.

\section{Uji Reliabilitas}


Uji reliabilitas bertujuan untuk mengetahui seberapa jauh sebuah alat ukur dapat dipercaya dan diandalkan. uji reliabilitas dilakukan dengan menggunakan metode Cronbac's Alpha. Jika cronbac alpha > o,6o maka dapat dikatakan reliabel. Adapun hasil uji reliabilitas pada penelitian ini sebagai berikut.

Tabel 4. Hasil Uji Reliabilitas

\begin{tabular}{|l|c|c|}
\multicolumn{1}{c}{ Reliability Statistics } \\
\hline Variabel & Cronbach's Alpha & N of Items \\
\hline Kinerja Karyawan Y & .905 & 16 \\
\hline Gaji $\left(\mathrm{X}_{1}\right)$ & .922 & 10 \\
\hline Tunjangan $\left(\mathrm{X}_{2}\right)$ & .938 & 10 \\
\hline
\end{tabular}

Sumber: Data diolah dari hasil SPSS Versi 22.

Hasil uji reliabilitas di atas pada kinerja karyawan diperoleh nilai cronbach alpha 0,905. Nilai cronbanch alpha 0,905 > 0,60 sehingga variabel kinerja karyawan dinyatakan reliabel dan dapat diterima. Hasil uji reliabilitas pada variabel gaji diperoleh nilai cronbach alpha 0,922. Nilai cronbach alpha 0,922 > 0,60 sehingga variabel gaji dinyatakan reliabel dan dapat diterima. Hasil uji reliabilitas dari tabel 4.7 variabel tunjangan diperoleh nilai cronbach alpha sebesar 0,938. Nilai cronbach alpha 0,938 > 0,60 sehingga variabel tunjangan dinyatakan reliabel dan dapat diterima.

\section{Uji Normalitas}

Uji normalitas digunakan untuk mengetahui apakah nilai residual yang diteliti berdistribusi normal atau tidak. Pada penelitian ini uji normalitas dilakukan berdasarkan pada metode uji one sample kolmogorov smirnov.

Tabel 5. Hasil Uji Normalitas

One-Sample Kolmogorov-Smirnov Test

\begin{tabular}{|ll|r|}
\hline & & $\begin{array}{c}\text { Unstandardized } \\
\text { Residual }\end{array}$ \\
\hline N & Mean & 27 \\
Normal Parameters ${ }^{\mathrm{a}, \mathrm{b}}$ & Mtd. & .0000000 \\
& Deviation & 4.36110916 \\
Most Extreme & Absolute & .095 \\
Differences & Positive & .095 \\
& Negative & -.086 \\
Test Statistic & & .095 \\
Asymp. Sig. (2-tailed) & & $.200^{\mathrm{c}, \mathrm{d}}$ \\
\hline
\end{tabular}

a. Test distribution is Normal.

b. Calculated from data.

c. Lilliefors Significance Correction. 
$\mathrm{d}$. This is a lower bound of the true significance.

Berdasarkan tabel di atas dilihat dari hasil uji normalitas bahwa nilai signifikansi (Asymp. Sig 2-tailed) sebesar 0,200. Nilai tersebut lebih besar dari nilai signifikansi o,10 $(0,200>0,10)$. Jadi dapat disimpulkan bahwa data tersebut berdistribusi normal.

\section{Uji Multikolinearitas}

Uji multikolinearitas bertujuan untuk menguji apakah pada model ditemukan adanya korelasi antara independent variable. Apabila nilai VIF (variance inflaction factor) kurang dari 10 dan nilai tolerance lebih dari o,1 maka dinyatakan tidak terjadi multikolinearitas.

Tabel 6. Hasil Uji Multikolinearitas

\section{Coefficients ${ }^{\mathbf{a}}$}

\begin{tabular}{|c|c|c|c|c|c|c|c|}
\hline \multirow[b]{2}{*}{ Model } & \multicolumn{2}{|c|}{$\begin{array}{l}\text { Unstandardized } \\
\text { Coefficients }\end{array}$} & \multirow{2}{*}{\begin{tabular}{|c|}
$\begin{array}{c}\text { Standar } \\
\text { dized } \\
\text { Coefficie } \\
\text { nts }\end{array}$ \\
Beta \\
\end{tabular}} & \multirow[b]{2}{*}{$\mathrm{t}$} & \multirow[b]{2}{*}{ Sig. } & \multicolumn{2}{|c|}{$\begin{array}{c}\text { Collinearity } \\
\text { Statistics }\end{array}$} \\
\hline & $\mathrm{B}$ & Std. Error & & & & Tolerance & VIF \\
\hline (Constant) & $34 \cdot 734$ & 4.038 & & 8.601 & $\begin{array}{r}.00 \\
0\end{array}$ & & \\
\hline Total_X1_Gaji & .382 & .282 & .365 & 1.354 & .188 & .167 & 5.997 \\
\hline $\begin{array}{l}\text { Total_X2_Tunjanga } \\
\text { n }\end{array}$ & .462 & .252 & .495 & & $\begin{array}{r}.07 \\
9\end{array}$ & .167 & 5.997 \\
\hline
\end{tabular}

a. Dependent Variable: Total_Y_Kinerja_Karyawan

Sumber: Data diolah dari hasil SPSS Versi 22

Berdasarkan tabel di atas diketahui bahwa nilai VIF dari variabel gaji sebesar 5,997< 10 dan variabel tunjangan sebesar 5,997 < 10. Maka dapat disimpulkan tidak terjadi multikolinearitas antara variabel independent. Sementara nilai tolerance dari gaji sebesar 0,167 > 0,1 dan variabel tunjangan sebesar 0,167>0,1. Maka dapat disimpulkan bahwa nilai tolerance dari keduan variabel independent lebih besar dari o,1 dari penilaian tersebut bahwa tidak terjadi multikolinearitas antara independent variable.

\section{Uji Heterokedastisitas}

Uji ini untuk melihat adanya ketidaksamaan varian dari residual untuk semua pengamatan pada model regresi. Metode yang diambil untuk melihat ketidaksamaan varian dari residual ialah uji spearman's rho. Jika nilai signifikan $>0,10$ maka dapat dinyatakan bahwa tidak terjadi masalah heteroskedastisitas.

Tabel 7. Hasil Uji Heterokestisitas

Correlations

\begin{tabular}{|c|c|c|c|c|c|}
\hline & & $\begin{array}{c}\text { Total_Y_K } \\
\text { inerja_Kar } \\
\text { yawan }\end{array}$ & $\begin{array}{c}\text { Total_X1 } \\
\text { Gaji }\end{array}$ & $\begin{array}{c}\text { Total_X2 } \\
\text { _Tunjang } \\
\text { an }\end{array}$ & $\begin{array}{c}\text { Unstandardized } \\
\text { Residual }\end{array}$ \\
\hline $\begin{array}{l}\text { Spe } \\
\text { arm }\end{array}$ & $\begin{array}{l}\text { Correlation } \\
\text { Coefficient }\end{array}$ & 1.000 & $.855^{* * *}$ & $.859^{* * *}$ & .327 \\
\hline
\end{tabular}




\begin{tabular}{|c|c|c|c|c|c|c|}
\hline $\begin{array}{l}\text { an's } \\
\text { rho }\end{array}$ & $\begin{array}{l}\text { Total_Y_Ki } \\
\text { nerja_Kary } \\
\text { awan }\end{array}$ & $\begin{array}{l}\text { Sig. (2- } \\
\text { tailed) } \\
\mathrm{N}\end{array}$ & $\begin{array}{r}\cdot \\
27 \\
\end{array}$ & $\begin{array}{r}.000 \\
27 \\
\end{array}$ & $\begin{array}{r}.000 \\
27 \\
\end{array}$ & $\begin{array}{r}.096 \\
27 \\
\end{array}$ \\
\hline & $\begin{array}{l}\text { Total_X1_ } \\
\text { Gaji }\end{array}$ & $\begin{array}{l}\text { Correlation } \\
\text { Coefficient } \\
\text { Sig. (2- } \\
\text { tailed) } \\
\text { N }\end{array}$ & $\begin{array}{r}.855^{* * *} \\
.000 \\
27\end{array}$ & • & $\begin{array}{r}.886^{* * *} \\
.000 \\
27\end{array}$ & $\begin{array}{r}-.039 \\
.847 \\
27\end{array}$ \\
\hline & $\begin{array}{l}\text { Total_X2_- } \\
\text { Tunjangan }\end{array}$ & $\begin{array}{l}\text { Correlation } \\
\text { Coefficient } \\
\text { Sig. (2- } \\
\text { tailed) } \\
\mathrm{N}\end{array}$ & $\begin{array}{r}.859^{* * *} \\
.000 \\
27\end{array}$ & $\begin{array}{r}.886^{* *} \\
.000 \\
27\end{array}$ & . & $\begin{array}{r}-.074 \\
.715 \\
27\end{array}$ \\
\hline & $\begin{array}{l}\text { Unstandar } \\
\text { dized } \\
\text { Residual }\end{array}$ & $\begin{array}{l}\text { Correlation } \\
\text { Coefficient } \\
\text { Sig. (2- } \\
\text { tailed) } \\
\mathrm{N}\end{array}$ & $\begin{array}{r}.327 \\
.096 \\
27\end{array}$ & $\begin{array}{r}-.039 \\
.847 \\
27\end{array}$ & $\begin{array}{r}-.074 \\
.715 \\
27\end{array}$ & 1.000 \\
\hline
\end{tabular}

**. Correlation is significant at the 0.01 level (2-tailed).

Sumber: Data diolah dari hasil SPSS Versi 22.

Dari tabel di atas hasil uji heterokedastisitas dapat diketahui bahwa nilai signifikan dari variabel gaji sebesar 0,847 > 0,10 dan variabel tunjangan sebesar 0,715 > 0,10. Jadi dari kedua variabel independent tersebut dapat dinyatakan tidak terjadi masalah heterokedastisitas pada model regresi.

\section{Uji Koefisien Determinasi $\left(R^{2}\right)$}

\section{Tabel 8. Hasil Uji Determinasi}

\begin{tabular}{|l|c|r|r|r|}
\multicolumn{6}{|c|}{ Model Summary } \\
\hline Model & \multicolumn{1}{c|}{$\mathrm{R}$} & R Square & $\begin{array}{c}\text { Adjusted R } \\
\text { Square }\end{array}$ & $\begin{array}{c}\text { Std. Error of the } \\
\text { Estimate }\end{array}$ \\
\hline 1 & $.842^{\mathrm{a}}$ & .709 & .685 & 4.539 \\
\hline
\end{tabular}

a. Predictors: (Constant), Total_X2_Tunjangan, Total_X1_Gaji

b. Dependent Variable: Total_Y_Kinerja_Karyawan

Berdasarkan hasil di atas diperoleh nilai R² (R Square) sebesar 0,709 atau 70,9\%. Hal ini menunjukkan bahwa persentase pengaruh variabel gaji dan tunjangan terhadap kinerja karyawan sebesar 70,9\%. Sedangkan sisanya sebesar 29,1\% dipengaruhi oleh variabel lain yang tidak dimasukkan dalam model penelitian ini.

\section{Analisis Regresi Berganda}

Analisi regresi berganda digunakan untuk mengetahui pengaruh variabel independen terhadap variabel dependen. Selain itu juga analisis regresi berganda digunakan untuk menguji kebenaran hipotesis yang diajukan dalam penelitian ini. 
Tabel 9. Analisis Regresi Berganda

Coefficients ${ }^{\mathbf{a}}$

\begin{tabular}{|c|c|c|c|c|c|c|c|}
\hline \multirow[b]{2}{*}{ Model } & \multicolumn{2}{|c|}{$\begin{array}{c}\text { Unstandardized } \\
\text { Coefficients }\end{array}$} & \multirow[t]{2}{*}{\begin{tabular}{|c|}
$\begin{array}{c}\text { Standar } \\
\text { dized } \\
\text { Coefficie } \\
\text { nts }\end{array}$ \\
Beta \\
\end{tabular}} & \multirow[b]{2}{*}{$\mathrm{t}$} & \multirow[b]{2}{*}{ Sig. } & \multicolumn{2}{|c|}{$\begin{array}{c}\text { Collinearity } \\
\text { Statistics }\end{array}$} \\
\hline & $\mathrm{B}$ & Std. Error & & & & Tolerance & VIF \\
\hline (Constant) & 34.734 & 4.038 & & 8.601 & .00 & & \\
\hline Total_X1_Gaji & .382 & .282 & .365 & 1.354 & .188 & .167 & 5.997 \\
\hline $\begin{array}{l}\text { Total_X2_Tunjanga } \\
\mathrm{n}\end{array}$ & .462 & .252 & .495 & 1.836 & $\begin{array}{r}.07 \\
9\end{array}$ & .167 & 5.997 \\
\hline
\end{tabular}

a. Dependent Variable: Total_Y_Kinerja_Karyawan

$$
\begin{aligned}
& \mathrm{KK}=\mathrm{a}+\mathrm{b}_{1} \mathrm{G}_{+} \mathrm{b}_{2} \mathrm{~T}_{+} \mathrm{e} \\
& \mathrm{KK}=34,734+0,382 \mathrm{G}+0,462 \mathrm{~T}+\mathrm{e}
\end{aligned}
$$

Konstanta sebesar 34,734 artinya apabila variabel gaji dan tunjangan dianggap konstanta maka kinerja karyawan adalah sebesar 34,734 satuan.

Koefisien regresi variabel gaji sebesar 0,382 satuan, apabila koefisien bernilai positif artinya terjadi hubungan positif antara gaji dengan kinerja karyawan, semakin tinggi gaji maka semakin meningkat kinerja karyawan.

Koefisien regresi variabel tunjangan sebesar 0,462 satuan, apabila koefisien bernilai positif artinya terjadi hubungan positif antara tunjangan dengan kinerja karyawan, semakin tinggi tunjangan maka semakin meningkat kinerja karyawan.

\section{Uji Koefisien Regresi secara Parsial (Uji-t)}

Uji-t atau parsial dilakukan untuk melihat secara parsial pengaruh signifikan antara variabel gaji, tunjangan terhadap variabel terikat yaitu kinerja karyawan. Adapun hasil dari uji signifikan parsial adalah sebagai berikut.

Tabel 1o. Uji Koefisien secara parsial (Uji-t)

\begin{tabular}{|c|c|c|c|c|c|c|c|}
\hline \multirow[b]{2}{*}{ Model } & \multicolumn{2}{|c|}{$\begin{array}{l}\text { Unstandardized } \\
\text { Coefficients }\end{array}$} & \multirow{2}{*}{$\begin{array}{c}\begin{array}{c}\text { Standar } \\
\text { dized } \\
\text { Coefficie } \\
\text { nts }\end{array} \\
\text { Beta }\end{array}$} & \multirow[b]{2}{*}{$\mathrm{t}$} & \multirow[b]{2}{*}{ Sig. } & \multicolumn{2}{|c|}{$\begin{array}{l}\text { Collinearity } \\
\text { Statistics }\end{array}$} \\
\hline & $\mathrm{B}$ & Std. Error & & & & Tolerance & VIF \\
\hline (Constant) & 34.734 & 4.038 & & 8.601 & .000 & & \\
\hline Total_X1_Gaji & .382 & .282 & .365 & 1.354 & 188 & .167 & 5.997 \\
\hline $\begin{array}{l}\text { Total_X2_Tunjanga } \\
\mathrm{n}\end{array}$ & .462 & .252 & .495 & 1.836 & .079 & .167 & 5.997 \\
\hline
\end{tabular}

\section{Coefficients ${ }^{\mathbf{a}}$}

a. Dependent Variable: Total_Y_Kinerja_Karyawan 
Berdasarkan tabel di atas Untuk $\mathrm{t}_{\text {tabel }}$ diperoleh dari rumus $\mathrm{df}=\mathrm{n}-\mathrm{k}-\mathbf{1}$ atau 27-2-1= 24, dengan menggunakan signifikan 10\%:2 = 5\% $(0,05)$. Hasil yang diperoleh untuk $t_{\text {tabel }}$ sebesar 1,710 jika $t_{\text {hitung }}>t_{\text {tabel }}$ maka $\mathrm{H}_{\mathrm{a}}$ diterima.

Berdasarkan tabel 4. 10 di atas dapat dilihat bahwa variabel gaji sebesar 1,354<1,710 maka $\mathrm{H}_{\mathrm{a}}$ ditolak $\mathrm{H}_{\mathrm{o}}$ diterima. Jadi dapat disimpulkan bahwa tidak terdapat pengaruh yang signifikan antara gaji terhadap kinerja karyawan pada Hotel Natama Syariah Padangsidimpuan secara parsial.

Pada variabel tunjangan sebesar 1,836 > 1,710 maka $\mathrm{H}_{\mathrm{a}}$ diterima $\mathrm{H}_{\mathrm{o}}$ ditolak. Jadi dapat disimpulkan bahwa terdapat pengaruh antara tunjangan terhadap kinerja karyawan pada Hotel Natama Syariah Padangsidimpuan secara parsial.

\section{Uji Signifikan Simultan (Uji F)}

Uji F dilakukan untuk melihat secara bersama-sama pengaruh signifikan semua variabel bebas antara gaji dan tunjangan secara simultan mempunyai pengaruh terhadap variabel terikat kinerja karyawan.

\section{Tabel 11. Hasil Uji Signifikan Simultan (Uji F)}

\section{ANOVAa}

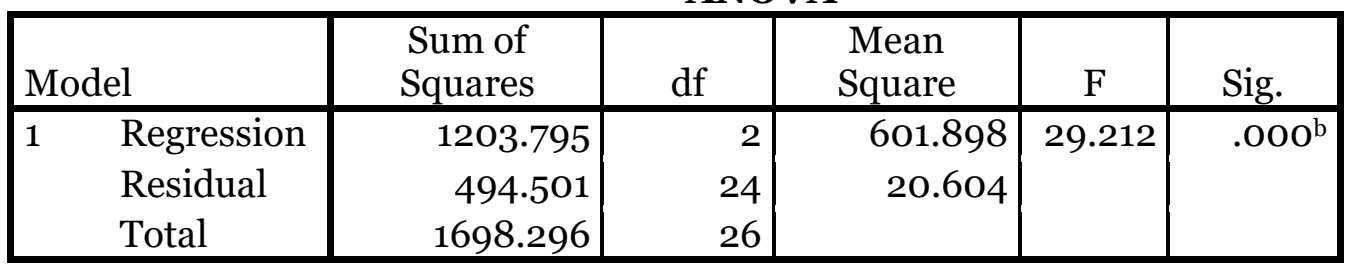

a. Dependent Variable: Total_Y_Kinerja_Karyawan

b. Predictors: (Constant), Total_X2_Tunjangan, Total_X1_Gaji

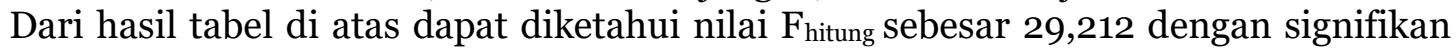
0,10 dengan df 27-2-1= 24. Hasil $F_{\text {tabel }}$ sebesar 2,54 $F_{\text {hitung }}>F_{\text {tabel }}$ artinya terdapat pengaruh antara gaji dan tunjangan secara bersama-sama (simultan) terhadap kinerja karyawan pada Hotel Natama Syariah Padangsidimpuan. Penelitian ini berjudul Pengaruh Gaji dan Tunjangan Terhadap Kinerja Karyawan Hotel Natama Syariah Padangsidimpuan.

Persamaan analisis regresi linear berganda diperoleh hasil sebagai berikut:

$$
\mathrm{KK}=34,734+0,382 \mathrm{G}+0,462 \mathrm{~T}+\mathrm{e} \text {. }
$$

Gaji (X1) secara parsial tidak mempunyai pengaruh terhadap kinerja karyawan dengan nilai $t_{\text {hitung }}<\mathrm{t}_{\text {tabel }}$ yaitu 1,354 $<1,710$. Maka, hasil penelitian ini bertentangan dengan teori ataupun tidak sesuai dengan teori yang mengatakan bahwa pemberian gaji atau penghargaan kepada karyawan dapat meningkatkan kinerja karyawan. Penelitian ini diperkuat dengan adanya tiga hasil penelitian terdahulu yang menyatakan bahwa gaji tidak berpengaruhi terhadap kinerja karyawan, seperti: 
Penelitian Guidio Erick Prabowo yang berjudul Pengaruh Persepsi Gaji dan Motivasi terhadap Kinerja Karyawan Universitas Sanata Dharma Yogyakarta, dengan hasil penelitian nilai $t_{\text {hitung }} 0,433<t_{\text {tabel }} 2,003$, yang menyatakan persepsi gaji tidak berpengaruh terhadap kinerja karyawan. Penelitian M. Ikhwan Maulana Haeruddin dengan judul Pengaruh Gaji dan Insentif terhadap Kinerja Karyawan dan Organisational Citizenship Behaviour (OCB) pada Hotel Grand Clarion di Makassar, yang menyatakan bahwa variabel gaji tidak berpengaruh secara signifikan terhadap kinerja karyawan. Hasil penelitian Firziyanah Mustika Utami yang berjudul Pengaruh Kompensasi dan Disiplin Kerja Terhadap Kinerja Karyawan Studi Kasus Pada PT. Gapura Omega Alpha Land Depok, dengan hasil penelitian kompensasi tidak berpengaruh terhadap kinerja karyawan dengan hasil uji $t_{\text {hitung }}$ sebesar 1,282 $<t_{\text {tabel }}$ 2,201.

Dapat ditarik kesimpulan dari beberapa penelitian di atas bahwa gaji tidak selalu dapat mempengaruhi kinerja karyawan meskipun gaji telah diberikan tepat waktu setiap bulannya. Menurut peneliti disini peran dari pimpinan ataupun manajer suatu perusahaan harus meninjau kembali apakah gaji atau penghargaan yang diberikan sudah cukup atau dapat memenuhi kebutuhan dan bagaimana agar kinerja karyawan lebih baik dan terus mengalami kemajuan. Begitu juga dengan karyawan harus bekerja dengan baik dengan memperhatikan sesuatu yang dapat membangkitkan semangat kerja seperti gaji, tunjangan dan penghargaan lainnya.

Tunjangan (X2) secara parsial mempunyai pengaruh yang signifikan terhadap kinerja karyawan dengan nilai $t_{\text {hitung }}>t_{\text {tabel }}$ yaitu 1,836 $>1,710$. Penelitian ini sesuai dengan teori yang mengatakan bahwa tunjangan (benefits) adalah satu bagian penting dari setiap upah dan pembayaran keuangan tidak langsung karyawan seperti, waktu cuti yang dibayar, asuransi jiwa dan kesehatan, dan fasilitas lainnya. Teori lain juga mengatakan tunjangan merupakan bentuk kompensasi pelengkap yang sering disebut fringe benefits adalah untuk mempertahankan karyawan dalam jangka panjang. Penelitian ini juga diperkuat oleh penelitian terdahulu Farikha Nur Khasanah yang berjudul Pengaruh Kompensasi dan Lingkungan Kerja Terhadap Kinerja Karyawan di Waroeng Spesial Sambal (Ss) Yogyakarta (Studi Pada Waroeng Ss Samirono Dan Jalan Kaliurang) dengan hasil penelitian kompensasi berpengaruh secara parsial terhadap kinerja karyawan.

Dapat diambil kesimpulan dari beberapa teori dan penelitian terdahulu yang mengatakan bahwa tunjangan ataupun kompensasi tidak langsung sangat mempengaruhi semangat kerja karyawan dalam suatu organisasi atau perusahaan dengan menjamin adanya asuransi jiwa dan kesehatan, cuti, pensiun dan fasilitas lainnya. Sehingga karyawan dapat bertahan bekerja dalam jangka panjang.

\section{KESIMPULAN}


Berdasarkan hasil penelitian tersebut maka dapat disimpulkan bahwa gaji (X1) secara parsial tidak mempunyai pengaruh terhadap kinerja karyawan dengan nilai $t_{\text {hitung }}<t_{\text {tabel }}$ yaitu $1,354<1,710$. Sedangkan tunjangan (X2) secara parsial mempunyai pengaruh yang signifikan terhadap kinerja karyawan dengan nilai $t_{\text {hitung }}>t_{\text {tabel }}$ yaitu 1,836 $>1,710$. Hal ini berimplikasi bahwa jika perusahaan ingin meningkatkan kinerja pegawainya maka harus memerhatikan faktor tunjangan yang diberikan kepada pegawainya.

\section{DAFTAR PUSTAKA}

Agus Sucipto. 2010. Studi Kelayakan Bisnis Malang: UIN Maliki Press

Bungin, M. Burhan. 2005. Metodologi Penelitian Kuantitatif . Jakarta: Kencana

Dedi Rianto Rahadi. 2010. Manajemen Kinerja Sumber Daya Manusia Malang: TUNGGAL MANDIRI PUBLISHING

Gary Dessler. 2007. Manajemen Sumber Daya Manusia Jakarta: PT. Indeks

Hasibuan, Malayu, S.P.2006. Manajemen Dasar Pengertian Dan Masalah Jakarta: PT. Bumi Aksara

Herman Sofyandi. 2008. Manajemen Sumber Daya Manusia Yogyakarta: GRAHA ILMU

Ike Kusdyah Rachmawati. 2008. Manajemen Sumber Daya Manusia Yogyakarta: CV. ANDI OFFSET

Mudrajad Kuncoro. 2013. Metode Riset Untuk Bisnis dan Ekonomi Jakarta : Erlangga

Sadili Samsudin. 2010. Manajemen Sumber Daya Manusia Bandung: Pustaka Setia

Sedarmayanti. 2011. Membangun dan Mengembangkan Kepemimpinan Serta Meningkatkan Kinerja Untuk Meraih Keberhasilan Bandung: PT. Refika Aditama

Sugiyono. 2012. Metodelogi Penelitian Bisnis Bandung: Alfabeta

Suharsimi Arikunto. 2003. Manajemen Penelitian (Jakarta: PT. Rineka Cipta

Sunardi dan Anita Primasitiwi. 2012. Bisnis Pengantar, Yogyakarta: PT. BUKU SERU

T. Hani Handoko, Manajemen Personalia dan Sumber daya Manusia. Edisi 2 Yogyakarta: BPFE 